\title{
ANALISA PENINGKATAN MUTU PEMELIHARAAN MESIN TERHADAP KELANCARAN PROSES PRODUKSI PADA PERUSAHAAN DOLOMITE
}

\author{
*(Titin \\ **(Isvi Chamidatul \\ Fakultas Ekonomi \\ Universitas Islam Lamongan
}

\begin{abstract}
ABSTRAK
Pemeliharaan dapat diartikan sebagai kegiatan untuk memelihara atau menjaga fasilitas atau peralatan produksi dan mengadakan perbaikan, penyesuaian atau penggantian yang diperlukan supaya terdapat suatu keadaan operasi produksi yang memuaskan sesuai dengan apa yang direncanakan. Hendaknya kegiatan harus dapat menjamin bahwa selama proses produksi berlangsung, tidak akan terjadi kemacetan kemacetan yang di sebabkan oleh mesin atau fasilitas produksi. Dari pembahasan tersebut maka dapat ditarik kesimpulan bahwa peningkatan mutu pemeliharaan mesin memiliki pengaruh secara signifikan terhadap kelancaran proses produksi dan terdapat hubungan antara peningkatan mutu pemeliharaan mesin terhadap kelancaran proses produksi berhubungan kuat. Oleh karena itu dengan mengadakan pemeliharaan mesin diharapkan kelancaran proses produksi dapat berjalan dengan lancar sesuai dengan apa yang telah direncanakan. Dan tidak ada kemacetankemacetan yang disebabkan oleh mesin produksi.
\end{abstract}

\section{Kata Kunci : Pemeliharaan Mesin, Kelancaran Proses Produksi}

\section{Pendahuluan}

Perkembangan peradaban manusia telah memacu peningkatan kebutuhan dan keinginan baik dalam jumlah, variasi jenis, dan tingkat mutu. Perkembangan ini menimbulkan tantangan untuk dapat memenuhi keinginan tersebut dengan cara meningkatkan kemampuan menyediakan dan menghasilkannya peningkatan kemampuan penyediaan atau produksi barang merupakan usaha yang harus dilakuakan oleh perusahaan untuk dapat memenuhi kebutuhan secara efektif dan efesien. Usaha ini dilakukan agar dicapai tingkat keuntungan yang diharapkan demi menjamin kelangsungan perusahaan.

Dalam mencapai tujuan dan sasaran secara efektif dan efesien, dikembangkanlah pemikiran dan pengkajian untuk mendapatkan caracara yang lebih baik. Tujuannya adalah untuk mengahasilkan pengeluaran yang optimal, sehingga dapat untuk mencapai sasaran secara tepat dalam waktu, jumlah, mutu dengan biaya yang efesien dengan memanfaatkan factor-faktor produksi. Factor produksi yang dimaksud meliputi tenaga manusia ( men ), bahan ( material ), dana ( money), serta mesin dan peralatan ( machines ) kekurangan salah satu factor produksi dapat menggangu proses produksi, artinya kelancaran proses produk dapat terhambat bila salah satu factor produksi mengalami kerusakan.

Menurut Arikunto (2008) Pemeliharaan merupakan suatu fungsi dalam suatu perusahaan pabrik yang sama pentingnya dengan fungsi-fungsi lain seperti produksi.hal ini karena apabila kita mempunyai peralatan atau 
fasilitas, maka biasanya kita selalu berusaha untuk tetap mempergunakan peralatan atau fasilitas tersebut. Demikian pula halnya dengan perusahaan pabrik, dimana pimpinan perusahaan tersebut akan selalu berusaha agar fasilitas atau peralatan produksinya dapat dipergunakan sehingga kegiatan produksinya dapat berjalan dengan lancar. Dalam usaha untuk dapat terus menggunakan fasilitas tersebut agar kesinambungan produk dapat terjamin, maka dibutuhkan kegiatan-kegiatan pemeliharaan dan perawatan, yang meliputikegiatan pengecekan, meminyaki, dan perbaikan perbaikan atas kerusakan kerusakan yang ada serta pengantian spear part atau komponen yang terdapat pada fasilitas tersebut.

Pemeliharaan dapat diartikan sebagai kegiatan untuk memelihara atau menjaga fasilitas atau peralatan produksi dan mengadakan perbaikan , penyesuaian atau penggantian yang diperlukan supaya terdapat suatu keadaan operasi produksi yang memuaskan sesuai dengan apa yang direncanakan. Meningkatkan mutu pemeliharaan mesin dapat menekan atau mengurangi kemacetan kemacetan menjadi sekecil mungkin.

Dalam masalah pemeliharaan ini perlu di perhatikan bahwa sering terlihat dalam suatu perusahaan kurang di perhatikan bidang pemeliharaan atau maintenance ini, sehingga terjadilah kegiatan pemeliharaan yang tidak teratur. Peranan yang penting dari kegiatan baru di ingat setelah mesin mesin yang dimiliki rusak dan tidak dapat berjalan sama sekali. Hendaknya kegiatan harus dapat menjamin bahwa selama proses produksi berlangsung, tidak akan terjadi kemacetan kemacetan yang di sebabkan oleh mesin atau fasilitas produksi.
Jadi dengan adanya kegiatan pemeliharaan ini maka fasilitas atau peralatan produksidapat dipergunakan sesuai dengan rencana, dan tidak mengalami kerusakan selama peralatan tersebut dipergunakan untuk proses produksi sebelum jangka waktu tertentu yang direncanakan tercapai. Sehingga dapatlah diharapkan proses produksi dapat berjalan lancar dan terjamin, dengan cara meningkatkat mutu pemeliharaan, oleh karena itu pemeliharaan mesin mesin produksi ini perlu di lakukan untuk mengetahui seberapa besar perhatian perusahaan dalam menerapkan sistem manajemen pemeliharaan mesin nya.

Sebagai perusahaan industri CV. BAGUS MULIA KEMANTREN, yang memproduksi pupuk dolomite, efesiensi operasional nya sangat di tunjang oleh mesin produksi unut mesin giling. Dengan demikian pemeliharaan disini memegang peranan yang penting dalam upaya mencegah timbul nya kemacetan mesin yang ada saat berlangsung nya operasional produksi penggilingan untuk itu biaya pemeliharaan yang di keluarkan cenderung meningkat dari tahun ke tahun, karena nya perlu peningkatan mutu pemeliharaan mesin secara efektif agar proses produksi berjalan dengan lancar.

Berdasarkan pembahasan tersebut diatas, maka dapat di rumuskan permasalahan sebagai berikut: (1) Adakah hubungan antara peningkatan mutu pemeliharaan mesinterhadap kelancaran proses produksi pada CV. BAGUS MULIA KEMANTREN. (2) Sejauh mana pengaruh peningkatan mutu pemeliharaan mesin terhadap kelancaran proses produksi pada $\mathrm{CV}$. BAGUS MULIA KEMANTREN. Dari permasalahan tersebut, maka penelitian ini bertujuan (1) Untuk mengetahui hubungan antara 
peningkatan mutu pemeliharaan mesin terhadap kelancaran proses produksi pada CV. BAGUS MULIA KEMANTREN. (2) Untuk mengetahui sejauh mana pengaruh peningkatan mutu pemeliharaan mesin terhadap kelancaran proses produksi pada $\mathrm{CV}$. BAGUS MULIA KEMANTREN.

\section{METODE PENELITIAN}

Penelitian ini menggunakan
pendekatan deskriptif kuantitatif
sesuai dengan namanya banyak di
tuntut mengunakan angka, mulai dari
pengumpulan data, penafsiran
terhadap data tersebut, serta penampilan dari hasilnya. Suharsimin Arikunto (2010 : 27). Dan dari pendekatan kuantitatif ini yaitu data yang diperoleh dari sampel dan populasi dalam penelitian tersebut kemudian di analisis sesuai dengan metode statistik yang digunakan kemudian diinterprestasikan. Dimana pemeliharaan mesin sebagai variabel bebas dan kelancaran proses produksi sebagai variabel terikat. Populasi dalam penelitian ini adalah seluruh data yang ada pada CV. BAGUS MULIA Kemantren Paciran Lamongan dan sampel dalam penelitian ini adalah data pemeliharaan mesin dan data produksi pada tahun 2013. Karena dalam hal ini peneliti meneliti perusahaan dolomite, yang datanya disajikan dalam bentuk bulan, peneliti menyajikan data dalam bentuk bulan alasanya karena pada perusahaan yang diteliti baru di ubah menjadi CV pada awal tahun 2013. Karna sebelumnya masih dalam bentuk UD. Pengumpulan data diperoleh dari interview, observasi dan dokumentasi. Serta alat analisis statistik yang digunakan adalah Regresi Linier Sederhana, Kefesien korelasi dan uji t.
Bagian ini memaparkan alasan data pemeliharaan mesin dan jumlah produksi menjadi sampel penelitian. Pemilihan lokasi peneliti di desa Kemantren Paciran Lamongan karena Kemantren Paciran lamongan merupakan salah satu desa yang strategis karena letaknya di jalan raya deandles yang merupakan jalan utama yang menghubungkan beberapa kota diantaranya kota surabaya dengan kota tuban, sehingga dengan mengadakan pemeliharaan mesin diharapkan agar selama proses produksi berlangsung tidak terjadi kemacetan yang disebabkan oleh mesin dan dapat meningkatkan proses produksi sesuai dengan apa yang telah direncanakan.

\section{PEMBAHASAN}

Dari hasil pengumpulan dan pengolahan data adalah menggunakan alat analisis : (1) koefisisen korelasi, yaitu koefisien korelasi digunakan untuk mengetahui hubungan antara variabel bebas (pemeliharaan mesin) dengan variabel terikat (proses produksi). Arikunto (2010 : 313) dan hasil yang diperoleh dari perhitungan koefisien korelasi yaitu 0,756 artinya bahwa pemeliharaan mesin mempunyai hubungn yang kuat terhadap kelancaran proses produksi pada CV. Bagus Mulia Kemantren Paciran Lamongan (2) ) Analisis regresi linier sederhana adalah suatu analisa yang melibatkan dua variabel dan dipergunakan untuk memperkirakan variabel satu dengan yang lainnya, (sudjana, $2005: 314$ ) dan juga digunakan untuk mengetahui pengaruh antara peningkatan mutu pemeliharaan mesin $(\mathrm{X})$ terhadap kelancaran proses produksi (Y). Pada CV. Bagus Mulia Kemantren Paciran Lamongan dan hasil yang diperoleh yaitu $\mathrm{Y}=1,596+0,802 \mathrm{X}$ artinya Nilai $0,802 \mathrm{X}$, menunjukkan bahwa 
pengaruh (X) Peningkatan mutu pemeliharaan mesin. Dan (Y) kelancaran proses produksi adalah positif, artinya semakin tinggi tingkat mutu pemeliharaan mesin ( $X)$, maka kelancaran proses produksi (Y) juga meningkat. (3) Uji t digunakan untuk menguji tingkat signifikan pengaruh variabel bebas terhadap variabel terikat secarah parsial (sendiri-sendiri) pada tingkat kepercayaan tertentu (Sudjana, 2005: 380).Dan hasil yang diperoleh yaitu $t$ hitung $>\mathrm{t}$ tabel yaitu $\mathrm{t}$ hitung 3,694 dan $\mathrm{t}$ tabel $=2,228$. Karena t hitung 3,694 >t tabel 2,228 . sehingga $\mathrm{H}_{\mathrm{a}}$ yang berbunyi ada pengaruh antara peningkatan mutu pemeliharaan mesin terhadap kelancaran proses produksi di terima. Sedangkan $\mathrm{H}_{\mathrm{o}}$ yang berbunyi tidak ada pengaruh antara peningkatan mutu pemeliharaan mesin terhadap kelancaran proses produksi di tolak. Dengan demikian dapat disimpulkan bahwa terdapat pengaruh antara peningkatan mutu pemeliharaan mesin terhadap kelancaran proses produksi.

Dari hasil penelitian mengenai Peningkatan Mutu Pemeliharaan Mesin maka dapat disimpulkan bahwa peningkatan mutu pemeliharaan mesin berpengaruh secara signifikan terhadap kelancaran proses produksi pada perusahaan Dolomite. Karana apabila mesin produksi mengalami kerusakan maka proses produksinya akan terhambat dan hal ini dibuktikan dengan hasil regresi linier sederhana yaitu $\mathrm{Y}=1,596+0,802 \mathrm{X}$. Nilai $\mathrm{a}=$ 1,596 artinya apabila perusahaan tidak melakukan kegiatan pemeliharaan mesin $\quad(\mathrm{X}=0)$ makapemeliharaan mesin naik sebesar 1,596 dan $b=0,802$ artinya apabila perusahaan melakukan kegiatan pemeliharaan mesin maka proses produksi naik sebesar 0,802, hubungan antar peningkatan mutu pemeliharaan mesin terhadap kelancaran proses produksi pada $\mathrm{CV}$. BAGUS MULIA Kemantren Paciran Lamongan berhubungan kuat hal ini dibuktikan dengan hasil koefisien korelasi yaitu $r=0,756$ dan $R=571$ artinya bahwa peningkatan mutu pemeliharaan mesin mempunyai hubungan yang kuat sebesar 57\% terhadap kelancaran proses produksi pada CV. Bagus Mulia Kemantren dan dari hasil perhitungan uji $t$ menunjukkan $\mathrm{t}$ hitung $>\mathrm{t}$ tabel yaitu 3,698> 2,228. Hasil dilapangan terlihat bahwa dengan melakukan peningkatan mutu pemeliharaan mesin pada perusahaan CV. BAGUS MULIA bisa mengurangi kemacetankemacetan atau kerusakan pada mesin produksi.

Dari hasil penelitian ditemukan bahwa hubungan antara peningkatan mutu pemeliharaan mesin terhadap kelancaran proses produksi pada CV. BAGUS MULIA Kemantren Paciran lamongan ini tergolong dalam interval 0,60-0,799, dan interprestasi tingkat hubungannya adalah kuat hal ini dibuktikan dengan hasil koefisien korelasi yaitu $\mathrm{r}=0,756$ dan $\mathrm{R}=57 \%$ artinya bahwa peningkatan mutu pemeliharaan mesin tersebut mempunyai hubungan yang kuat sebesar 57\%, dan dari hasil perhitungan uji $\mathrm{t}$ menunjukkan $\mathrm{t}$ hitung $>\mathrm{t}$ tabel yaitu 3,698>2,228 dan peningkatan mutu pemeliharaan mesin berpengaruh secara signifikan terhadap kelancaran proses produksi Dolomite pada CV. BAGUS MULIA Kemantren Paciran Lamongan. Hal ini dibuktikan dengan hasil regresi linier sederhana $\mathrm{Y}=\mathrm{a}+\mathrm{b} X$, Yaitu $\mathrm{Y}=1,596$ $+0,802 \mathrm{X}$, artinya nilai $\mathrm{a}=1,596$ adalah apabila perusahaan tidak melakukan kegiatan pemeliharaan mesin $(X=0)$ maka kelancaran proses produksinya naik sebesar 1,596 dan $b=$ 0,802 artinya apabila perusahaan melakukan kegiatan pemeliharaan 
mesin maka tingkat kerusakan produk naik sebesar 0,802. Hal ini sesuai dengan penelitian yang pernah dilakukan oleh Moh. Irhamni (2010) dalam penelitian " pentingnya pengendalian intern suku cadang untuk meningkatkan efisiensi biaya pemeliharaan mesin pada PT. Sari Bumu Golokan Sidayu Gersik" sesuai dengan penelitian ini pengendalian intern suku cadang mempengarui efesiensi biaya pemeliharaan mesin,maka dapat ditarik kesimpulan sebagai beikut: dari perhitungan persamaan regresi linier sederhan diperoleh hasil $\mathrm{Y}=3,948+0,749 \mathrm{X}$, Hal ini menunjukkan ada hubungan yang positif. Artinya semakin besar tingkat pengendalian internsuku cadang maka efesiensi biaya pemeliharaan juga akan meningkat. Dan dari perhitungan korelasi dapat diartikan bahwa perhitungan korelasi sebesar 0.718 , artinya ada hubungan linier positif antara pengendalian intern suku cadang terhadap efsiensi biaya pemeliharaan mesin.dng (X) terhadap efisiensi biaya pemeliharaan mesin. Sedangkan untuk hasil uji $t$ diperoleh thitung 3,301 > t tabel 2,228 sehingga Ha berbunyi ada penggaruh antara pengendalian intern suku cadang terhadappeningkatan efesiensi biaya pemeliharaan mesin ditolak. Dengan demikian dapat disimpulkan bahwa terdapat hubungan yang kuat antara pengendalian intern suku cadang terhadap peningkatan efisiensi biaya pemeliharaan mesin. Dan dari hasil penelitian Misbakhus sholikhin (2012) ini tidak sama dengan penelitian sejenis karena menggunakan dua variabel dalam penelitian " Peranan Lay Out (penetapan barang) dan Perawatan Mesin Terhadap Kecepatan Proses Produksi Pada UD. Kurni Baru Gersik" mengemukakan bahwa perusahaan dalam proses produksi barang serta kecepatan. Hal ini di tunjukan oleh hasil analisis regresi berganda $\mathrm{Y}=-70,4,14\left(\mathrm{X}_{\mathrm{I}}\right)+5,98\left(\mathrm{X}_{2}\right)$ dari persamaan tersebut artinya apabila peranan layout dan penataan mesin tidak melakukan kegiatan $\left(X_{1} X_{2}=0\right)$ maka kecepatan proses produksinya berkurang sebesar -70,50sedangkan hasil analisis korelasi menunjukkan hasil $r_{1}$ peranan lay out 1,69 lebijh besar dari $r_{2}$ penataan mesin sebesar 4,84 dari hasil perhitungan menunjukan bahewa hasil uji $t_{1 \text { hitung }} 13,29>t_{\text {tabel }}$ sebesar 2,010, sehingga dari keadaan tersebut dapat di tarik kesimpulan Ho ditolak dan Hi diterima yang berarti variabel peranan layout dan penataan mesin kredit terhadap kecepatan proses produksi pada perusahaan.

\section{KESIMPULAN DAN SARAN SIMPULAN}

Hasil penelitian menunjukkan bahwa hubungan antara peningkatan mutu pemeliharaan mesin terhadap kelancaran proses produksi pada CV. Bagus Mulia Kemantren Paciran Lamongan berhubungan kuat. Hal ini dibuktikan dengan hasil koefisien korelasi yaitu : $\mathrm{r}=0,756$ dan $\mathrm{R}=$ 0,571 artinya bahwa peningkatan mutu pemeliharaaan mesin berhubungan kuat sebesar 57\%. Sedangkan dari hasil perhitungan uji t menunjukkan $\mathrm{t}$ hitung > t tabel yaitu 3,694 > t tabel 2,228 dimana Ho ditolak dan $\mathrm{Ha}$ diterima. Sehingga $\mathrm{Ha}$ berbunyi ada pengaruh antara peningkatan mutu pemeliharaan mesin terhadap kelancaran proses produksi diterima. Sedangkan Ho berbunyi tidak ada pengaruh antara peningkatan mutu pemeliharaan mesin terhadap kelancaran proses produksi ditolak. Dengan demikian dapat disimpulkan bahwa terdapat pengaruh yang kuat antara peningkatan mutu pemeliharaan 
mesin terhadap kelancaran proses produksi. Dan dari perhitungan persamaan regresi linier sederhana diperoleh hasil $\mathrm{Y}=1,596+0,802 \mathrm{X}$, berdasarkan penelitian menggunakan analisis regresi sederhana maka dapat diketahui bahwa nilai regresi dari variabel bebas adalah positif, hal ini menunjukkan ada pengaruhantara peningkatan mutu pemeliharaan mesin terhadap kelancaran proses produksi. artinya semakin besar mutu pemeliharaan mesin maka proses produksi juga akan meningkat

\section{SARAN}

Setelah kami menganalisa dan menyimpulkan masalah yang ada di CV. Bagus Mulia Kemantren Paciran Lamongan maka kami mengemukakan beberapa saran yang dapat di jadikan bahan pertimbangan untuk mengambil keputusan mengenai peningkatan mutu pemeliharaan mesin pada masa yang akan datang adalah sebagai berikut : (1) Ada baiknya di samping perusahaan melaksanakan peningkatan mutu pemeliharaan mesin perusahaan juga meningkatkan ketelitian kerja mekanik mesin- mesin produksi. Serta Mengadakan kegiatan monitoring pada mesin-mesin yang sering mengalami kerusakan pada saat produksi. Sehingga semakin besar mutu pemeliharan mesin tersebut maka proses produksi juga akan semakin meningkat.

(2) Penyusunan perencanaan dan jadwal pemeliharaan yang meliputi tugas yang dilaksanakan sesuai prioritas dan tenaga kerja yang akan melaksanakannya. Dan Tersedianya spearpats dalam perusahaan sehingga apabila ada kerusakan pada mesin bisa langsung diperbaiki. Dengan demikian terdapat hubungan yang erat antara peningkatan mutu pemeliharaan mesin terhadap kelancaran proses produksi.

\section{DAFTAR PUSTAKA.}

Assauri,Sofjan.2008.Manajemen Produksi dan Operasi. Jakarta: Lembaga Penerbit Fakultas Ekonomi Universitas Indonesia.

Handoko, Hani. 2010. Dasar-dasar Manajemen Produksi dan Operasi Yogyakarta: BPFE

Pardede, Pontas. 2005. Manajemen Operasi dan Produksi Teori, Model, dan Kebijakan

Aris. 2012. Teori Ekonomi Produksi. Surabaya: Brilian Internasional

Arikunto, Suharsimi.2010. Prosedur penelitian Suatu Pendekatan Praktik. Rineka Cipta.

Sudjana, 2005.MetodeStatistika. Bandung: Tarsito.

Misbakhus holikhin, 2012.peranan layout(penetapan barang) dan perawatan mesin terhadap kecepatan proses produksipada UD. Kurni Baru Gresik.Skripsi Fakultas Ekonomi, Tidak dipublikasikan. Universitas Islam Lamongan.

Moh. Irhamn, 2010. Pentingnya pengendalian intern suku cadang untuk meningkatkan efisiensi biaya pemeliharaan mesinpada PT. Sari Bumi Sidayu Gresik.Skripsi Fakultas Ekonomi, Tidak dipublikasikan. Universitas Islam Lamongan. 